\title{
PENGARUH MOTIVASI, KEPUASAN KERJA DAN KEDISIPLINAN TERHADAP TURN OVER KARYAWAN: PENDEKATAN KONSEP
}

\author{
Yulius Irwanto Putera Suwandi Hutomo', Lenny Christina Nawangsari2 \\ 1,2 Magister Manajemen, Universitas Mercu Buana \\ Email: yulius.piun@gmail.com, Lenny.christina@mercubuana.ac.id
}

\begin{abstract}
Abstrak: Penelitian ini bertujuan untuk menjelaskan analisa dan hubungan antara pengaruh suatu variable bebas yang masing-masing terdiri dari variabel motivasi (X1), variable kepuasan kerja (X2) dan variable kedisiplinan karyawan (X3) baik secara masing-masing variable ataupun secara keseluruhan terhadap turnover karyawan $(\mathrm{Y})$ sebagai variable terikat. Kelanjutannya, tujuan dari beberapa penelitian yang mengamati antar hubungan variable-variabel motivasi, kepuasan kerja dan kedisiplinan karyawan diharapkan dapat mengembangkan tujuan -tujuan penelitian selanjutnya.
\end{abstract}

Kata Kunci: motivasi; kepuasan kerja; kedisiplinan karyawan dan turnover karyawan

Abstract: The objective of this article is to describe a correlation and to analyze the influence of some variables, which are: motivation variable (X1), job satisfaction variable (X2) and employee discipline variable (X3) as an independent variables where partially or simultaneously towards employee turnover $(Y)$ as a dependent variable. Next, some possible/s research objective could observing the relationship of variables of motivation, job satisfaction and employee discipline, those are highly expecting to develop the studies objective.

Keywords: Motivation; job satisfaction; employee discipline and employee turnover

\section{PENDAHULUAN}

Di dunia sekarang ini karyawan menghadapi lingkungan yang sangat tidak pasti dan dinamis sehubungan dengan pekerjaan dan karier mereka. Semua orang menginginkan masa depan tertentu dimana kehidupan mereka dan kehidupan keluarga mereka aman. Akibatnya, karyawan selalu mencari peluang yang memungkinkan untuk lebih baik, kondisi kerja yang jauh lebih baik, karir yang juga lebih baik serta perkembangan kesuksesan dalam organisasi. Alasan utama tingginya tingkat turnover dalam organisasi adalah aspek moneter. Orang berubah untuk kompensasi yang lebih baik. Turnover karyawan menjadi masalah utama, terutama di bidang human capital. Banyak alasan untuk para karyawan dalam meninggalkan perusahaan dan berpaling untuk pindah ke perusahaan yang lain, diantaranya adalah faktor kepemimpinan manajemen perusahaan, stress di tempat kerja, budaya organisasi yang tidak mendukung, faktor kepuasan bekerja, latar belakang motivasi bekerja maupun kedisiplinan karyawan yang tidak menunjang tuntutan perusahaan.

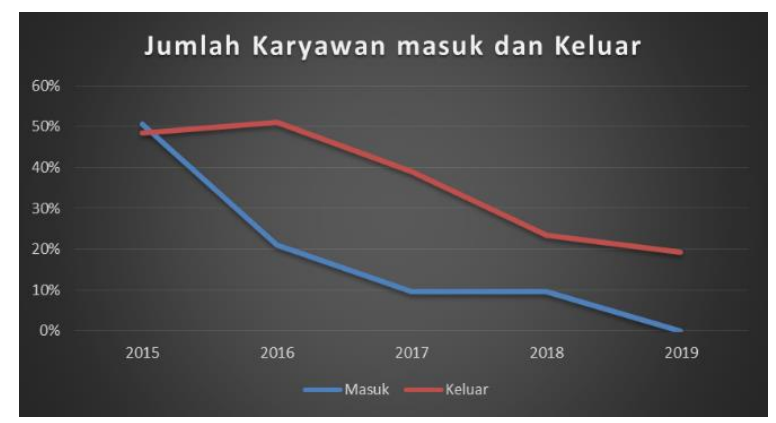




\section{Gambar1}

Data rekrutmen dan pengunduran diri dari suatu perusahaan Ritel

Penulis melakukan pra survey terhadap 30 orang responden terkait faktor-faktor yang mempengaruhi turnover karyawan dan didapatkan 3 faktor tertinggi, yaitu:

1. Motivasi

2. Kepuasan bekerja

3. Kedisiplinan

Tabel 1

Hasil Kuantifikasi pra-survey

\begin{tabular}{|c|c|c|}
\hline No. & Faktoryang me mpengaruhi tumover karyawan & $\mathrm{s}$ \\
\hline 1. & Stress di tempat kerja & 2 \\
\hline 2. & Gaya kepeminpinan & 3 \\
\hline 3. & Kepuasan bekerja & 7 \\
\hline 4. & Motivasi bekerja & 10 \\
\hline s. & Budaya organsasi & 2 \\
\hline \multirow[t]{2}{*}{6.} & Kedisiplinn bekerja & 6 \\
\hline & Total responden & 30 \\
\hline
\end{tabular}

Sumber: Data pra survey diolah dan dihitung oleh peneliti (2019)

Dari hasil pra survey yang tertera diatas, peneliti melakukan pra survey yang lebih mendalam terhadap 3 variabel tertinggi yang dapat mempengaruhi turnover karyawan, yaitu sebagai berikut:

\section{Tabel 2}

Hasil Pra Survey Motivasi

\begin{tabular}{ccccccccccc}
\hline No & \multicolumn{1}{c}{ Pernyataan } & & SS & S & N & TS & STS & $\begin{array}{l}\text { Total Rata-rata } \\
\text { Skor }\end{array}$ & Skor \\
\hline 1 & $\begin{array}{l}\text { Saya menikmati kepuasan } \\
\text { penyelesaian tugas yang sulit. }\end{array}$ & dari & 0 & 5 & 11 & 14 & 0 & 81 & 2,7 \\
\hline $\begin{array}{l}\text { Saya ingin tahu bagaimana kemajuan } \\
\text { yang saya capai ketika sedang } \\
\text { menyelesakan tugas. }\end{array}$ & 1 & 0 & 16 & 13 & 0 & 79 & 2,63 \\
\hline 3 & $\begin{array}{l}\text { Saya menikmati bagian dari kelompok } \\
\text { organisasi. }\end{array}$ & 2 & 5 & 5 & 18 & 0 & 81 & 2,7 \\
\hline Rata-rata & & & & & & & \\
\hline
\end{tabular}

Sumber: Data pra survey diolah dan dihitung oleh peneliti (2019)

Merujuk pada tabel 2, kita dapat mengetahui bahwa karyawan tidak menikmati kepuasan dari penyelesaian tugas-tugas yang sulit, hal ini dapat terbukti dari jawaban responden. Karyawan juga diketahui kurang mengetahui kemajuan yang karyawan capai ketika sedang menyelesaikan tugas. Kemudian juga karyawan tidak menikmati bagian dari kelompok organisasi.

\section{Tabel 3}

\section{Hasil Pra Survei Kepuasan Kerja}

\begin{tabular}{clccccccc}
\hline No & \multicolumn{1}{c}{ Pernyataan } & SS & S & N & TS & STS & $\begin{array}{c}\text { Total Rata-rata } \\
\text { Skor }\end{array}$ & Skor \\
\hline 1 & $\begin{array}{l}\text { Carrefour ITC BSD memberikan gaji } \\
\text { yang lebih baik dari perusahaan hin. }\end{array}$ & 0 & 0 & 14 & 16 & 0 & 74 & 2,46 \\
\hline 2 & $\begin{array}{l}\text { Jenjang promosi diCarrefour ITC BSD } \\
\text { sangat baik }\end{array}$ & 0 & 0 & 9 & 21 & 0 & 69 & 2,3 \\
\hline 3 & $\begin{array}{l}\text { Saya merasa senang dengan tingkat } \\
\text { tanggung jawab dahmpekerjaan saya. }\end{array}$ & 0 & 8 & 12 & 10 & 0 & 88 & 2,93 \\
\hline Rata-rata & & & & & & & & 2,56 \\
\hline
\end{tabular}


Sumber: Data pra survey diolah dan dihitung oleh peneliti (2019)

Berdasarkan tabel 3, dapat diketahui bahwa perusahaan tidak memberikan gaji yang lebih baik dari perusahaan lain. Kemudian karyawan di perusahaan tidak baik dalam jenjang promosi jabatan, hal ini salah satu penyebab terjadinya turnover pada karyawan.

Selain itu juga karyawan kurang merasa nyaman/senang dengan tingkat tanggungjawab dalam pekerjaan yang ditanganinya.

Tabel 4

\begin{tabular}{cccccccccc}
\multicolumn{8}{c}{ Hasil Pra Survei Kedisiplinan } \\
\hline No & \multicolumn{1}{c}{ Pernyataan } & SS & S & N & TS & STS & $\begin{array}{c}\text { Total } \\
\text { Skor }\end{array}$ & $\begin{array}{c}\text { Rata-rata } \\
\text { Skor }\end{array}$ \\
\hline $\mathbf{1}$ & $\begin{array}{l}\text { Saya hadir tepat waktu dikantor setiap } \\
\text { hari jam kerja }\end{array}$ & 0 & 5 & 11 & 14 & 0 & 81 & 2,7 \\
\hline $\mathbf{2}$ & $\begin{array}{l}\text { Saya melaksanakan tugas dengan penuh } \\
\text { tanggung jawab }\end{array}$ & 0 & 2 & 10 & 18 & 0 & 72 & 2,4 \\
\hline $\mathbf{3}$ & $\begin{array}{l}\text { Saya mematuhi peraturan } \\
\text { ditetepkan dikantor }\end{array}$ & yang & 0 & 9 & 15 & 6 & 0 & 93 & 3,1 \\
\hline Rata-rata & & & & & & & 2,73 \\
\hline
\end{tabular}

Sumber: Data pra survey diolah dan dihitung oleh peneliti (2019)

Berdasarkan tabel 4, dapat dilihat dari hasil pra survey bahwa kurangnya kedisiplinan karyawan yang hadir tepat waktu dikantor setiap hari dan kurang dalam melaksanakan tugas dengan penuh tanggung jawab. Walaupun, karyawan mematuhi peraturan yang ditetapkan dikantor sedikit lebih baik dibandingkan kedua point awal. Hal tersebut membuktikan bahwa kedisiplina karyawan pada perusahaan masih kurang.

\section{METODE PENELITIAN}

Menelaah hasil pra survey terhadap variable-variabel tersebut yang berpengaruh terhadap turnover karyawan dapat diidentifikasikan sebagai berikut:

1. Karyawan kurang termotivasi dalam bekerja di perusahaan, terlihat dari hasil pra-survey dengan rata-rata skala Likert sebesar 2,67

2. Karyawan merasa ketidakpuasan dalam berkerja, terlihat dari hasil pra-survey dengan skala Likert sebesar 2,56

3. Karyawan memiliki kedisiplinan yang kurang, terlihat dari hasil pra-survey dengan ratarata skala Likert sebesar 2,73

Menilik latar belakang dan juga identifikasi masalah tersebut di atas, dapat disimpulkan bahwa permasalahan yang ada cukup kompleks, sehingga perlu kiranya ada pembatasan masalah yang akan diteliti secara lebih mendalam.

\section{HASIL DAN PEMBAHASAN}

\section{Pengaruh Motivasi Terhadap Turnover Karyawan.}

Menurut (Hassan et al., 2012) motivasi merupakan proses dimana seorang mempunyai dorongan secara berkelanjutan untuk sebuah pencapaian tertentu. Hal ini memiliki 3 elemen kunci, yaitu: energi, arah, dan ketekunan. (Chodera et al., 2011) menyatakan bahwa turnover intention merupakan hasil atas evaluasi individu berkaitan kelanjutan hubungan orang tersebut dengan perusahaan tempat dimana dia bekerja tetapi belum diwujudkan dalam tindakan nyata. Mengacu kajian literatur tersebut dapat di simpulakan hipotesis sebagai berikut:

Hipotesis1: Motivasi mempunyai pengaruh significant terhadap turnover karyawan. 


\section{Pengaruh Kepuasan Kerja terhadap Turnover Karyawan.}

Menurut (Hassan et al., 2012), kepuasan kerja mengacu kepada sikap dasar karyawan terhadap pekerjaannya. (Chodera et al., 2011) juga menyatakan jika turnover intention merupakan hasil evaluasi individu tersebut berkaitan kelanjutan hubungannya dengan perusahaan tempat yang bersangkutan bekerja tetapi belum diwujudkan dalam tindakan secara nyata. Penelitian ini di dukung oleh (Lestari \& Mujiati, 2018) kepuasan kerja mempunyai pengaruh negatif dan berhubungan secara signifikan terhadap turnover intention. Kepuasan atas gaji yang diterima dapat memprediksi tingkat absensi dan turnover karyawan. Beberapa penelitian lain menyimpulkan banhwa hubungan antara kepuasan gaji dengan intensi keluar adalah negatif (Motowidlo, 1983), (Lum et al., 1998), (Hidayati \& Trisnawati, 2016). Model kepuasan atas gaji yang diterima dapat menunjukan kelanjutan konsep equity theory. Teori equity menekankan atas kepuasan gaji disebabkan oleh perasaan seseorang yang mempunyai hubungan dengan rasa keadilan terhadap gaji yang diterimanya. Para pekerja yang tidak merasa dapat terpuaskan dengan pekerjaan yang dimilikinya cenderung untuk dapat melakukan cara yang mengganggu kinerja organisasi tempatnya bekerja, yaitu berupa: turnover yang tinggi, tingkat absensi yang juga tinggi serta kelambanan dalam bekerja, keluhan atau bahkan menyebabkan mogok kerja. Berdasarkan kajian literature di atas dapat di simpulakan hipotesis sebagai berikut:

Hipotesis2: Kepuasan kerja mempunyai pengaruh significant terhadap turnover karyawan.

\section{Pengaruh Kedisiplinan Terhadap Turnover Karyawan}

Kesadaran dan kesediaan karyawan mentaati semua peraturan yang ditetapkan oleh perusahaan dan norma-norma sosial yang berlaku haruslah sebagai bentuk penerimaan karyawan tersebut atas organisasi perusahaan tempatnya bekerja. Didalam menjalankan aktifitas bekerja, pegawai yang datang ke kantor dan pulang tepat waktunya, mengerjakan semua pekerjaannya dengan baik, dapat mematuhi semua peraturan perusahaan dan juga norma-norma sosial yang berlaku dapat mencerminkan kenyamanan pegawai yang juga mencegah keinginan para karyawan untuk meninggalkan perusahaan. Hal ini didukung juga oleh hasil penelitian lainnya yang dilakukan oleh (Varin et al., 2010), menyatakan bahwa mendidik penyelia mengenai aturan-aturan dapat memberi mereka keseimbangan yang tepat diantara otoritas dan penerimaan. Hasilnya dapat ditunjukan dengan tingkat turnover yang rendah tetapi mempunyai hasil produktivitas yang tinggi bagi organisasi.

Hipotesis 3: Kedisiplinan mempunyai pengaruh significant terhadap turnover karyawan.

\section{Pengaruh Motivasi, Kepuasan Kerja dan Kedisiplinan Terhadap Turnover Karyawan.}

Organisasi dan manajemen dapat memberi pengaruh terhadap karyawan dalam melakukan tindakan yang kurang baik, seperti: indisipliner. Kendala bagi para pegawai dalam berinteraksi dengan rekan kerja, gangguan pikiran dapat menimbulkan situasi bekerja yang tidak nyaman, sehingga pada akhirnya karyawan dapat mulai 
berpikir untuk meninggalkan perusahaan tempatnya bekerja dan mencari tempat bekerja di perusahaan lain yang mereka pikir lebih baik. Pemikiran hal seperti ini didukung oleh penelitian yang dilakukan (Nahar et al., 2013) yang menjabarkan bahwa jika orang-orang merasa puas dengan pekerjaan mereka, mereka akan lebih produktif dalam bekerja dan cenderung lebih sehat. Tetap ketika karyawan merasa bahwa lingkungan di tempat kerjanya negatif, maka mereka dapat merasa stres.

Menurut (Ayers et al., 2010) memberi pernyataan bahwa hasil penelitiannya menunjukan bahwa disiplin yang tepat akan dapat memberikan peningkatkan kepuasan terhadap karyawan, yang juga meningkatkan kinerja, dan melindungi perusahaan dari tuntutan hukum mahal. Mendidik penyelia berkaitan dengan aturanaturan ini akan dapat memberi keseimbangan yang tepat antara otoritas dan penerimaan, sehingga memberi hasil berupa turnover yang rendah dan produktivitas hasil kerja yang tinggi bagi organisasi. Selanjutnya (Saeed et al., 2014) membuktikan jika ada pengaruh yang cukup signifikan antara kepuasan karyawan terhadap intensi turnover karyawan. Mengacu kepada kajian teori dan penelitian yang terdahulu maka dapat disusun kerangka penelitian ini.

Hipotesis 4: Motivasi, Kepuasan Kerja dan Kedisiplinan secara simutan mempunyai pengaruh terhadap Turnover karyawan.

\section{KESIMPULAN}

Berkaitan atas permasalahan yang dibahas dan dikemukakan dalam penjabaran artikel ini, yang membutuhkan jawaban konseptual maka beberapa variable seperti variable motivasi, variable kepuasan kerja dan variable kedisiplinan dapat disimpulkan berpengaruh terhadap turnover karyawan. Mengacu kepada kajian teori dan studi empiris, maka artikel ini dapat disimpulkan dan dikemukakan secara lebih detail sebagai berikut: (1) Motivasi dan Kepuasan Kerja bisa saling pengaruh mempengaruhi; (2) Motivasi mempunyai pengaruh terhadap Kedisiplinan; (3) Kepuasan Kerja mempunyai pengaruh terhadap Kedisiplinan; (4) Motivasi dan Kepuasan Kerja mempunyai pengaruh terhadap Kedisplinan; (5) Motivasi, Kepuasan Kerja dan Kedisiplinan mempunyai pengaruh terhadap turnover Karyawan.

\section{SARAN}

Denga penelitian yang telah dilakukan sesuai tujuan penelitian yang dapat menguji konseptual bagan kerja pada organisasi perdagangan dan ritel sangat disarankan agar dapat meningkatkan sumbangan ilmu, khususnya pada human capital.

\section{UCAPAN TERIMAKASIH}

Ucapan terima kasih penulis sampaikan kepada seluruh narasumber yang bersedia membantu dan memberikan informasi yang diperlukan pada penelitian ini. Ucapan terima kasih juga kami sampaikan kepada para pihak yang membantu dalam selesainya tulisan ini. 


\section{REFERENSI}

Ayers, K. L., Gallet, A., Staccini-Lavenant, L., \& Thérond, P. P. (2010). The long-range activity of Hedgehog is regulated in the apical extracellular space by the glypican Dally and the hydrolase Notum. Developmental Cell, 18(4), 605-620.

Chodera, J. D., Mobley, D. L., Shirts, M. R., Dixon, R. W., Branson, K., \& Pande, V. S. (2011). Alchemical free energy methods for drug discovery: progress and challenges. Current Opinion in Structural Biology, 21(2), 150-160.

Hassan, M., Toylan, N. V., Semerciöz, F., \& Aksel, I. (2012). Interpersonal trust and its role in organizations. International Business Research, 5(8), 33.

Hidayati, N., \& Trisnawati, D. (2016). Pengaruh Kepuasan Kerja Dan Stress Kerja Terhadap Turnover Intentions Karyawan Bag. Marketing Pt. Wahana Sahabat Utama. Eksis: Jurnal Riset Ekonomi Dan Bisnis, 11(1).

Lestari, N. N. Y. S., \& Mujiati, N. W. (2018). Pengaruh stres kerja, komitmen organisasi, dan kepuasan kerja karyawan terhadap turnover intention. Udayana University.

Lum, L., Kervin, J., Clark, K., Reid, F., \& Sirola, W. (1998). Explaining nursing turnover intent: job satisfaction, pay satisfaction, or organizational commitment? Journal of Organizational Behavior: The International Journal of Industrial, Occupational and Organizational Psychology and Behavior, 19(3), 305-320.

Motowidlo, S. J. (1983). Predicting sales turnover from pay satisfaction and expectation. Journal of Applied Psychology, 68(3), 484.

Nahar, J., Imam, T., Tickle, K. S., \& Chen, Y.-P. P. (2013). Association rule mining to detect factors which contribute to heart disease in males and females. Expert Systems with Applications, 40(4), 1086-1093.

Saeed, I., Waseem, M., Sikander, S., \& Rizwan, M. (2014). The relationship of turnover intention with job satisfaction, job performance, leader member exchange, emotional intelligence and organizational commitment. International Journal of Learning and Development, 4(2), 242-256.

Varin, S., Cliquet, J.-B., Personeni, E., Avice, J.-C., \& Lemauviel-Lavenant, S. (2010). How does sulphur availability modify $\mathrm{N}$ acquisition of white clover (Trifolium repens L.)? Journal of Experimental Botany, 61(1), 225-234. 